Bangladesh J. Bot. 49(4): 919-925, 2020 (December)

\title{
BIOCHEMICAL CHANGES IN RIDGE GOURD ( LUFFA ACUTANGULA L.) CULTIVARS INDUCED BY ROOT KNOT NEMATODES
}

\author{
Ritu Kumari Pandey* ${ }^{1}$ and DK Nayak \\ Department of Nematology, College of Agriculture, Odisha University of \\ Agriculture and Technology, Bhubaneswar-751003, Odisha, India
}

Keywords: Biochemical changes, Meloidogyne incognita, Ridge gourd

\begin{abstract}
Biochemical changes in different ridge gourd cultivars inoculated with Meloidogyne incognita were investigated. All the parameters showed higher activity during post infection period, both at shoots and roots level. Cultivar Priya had significant higher activity of phenylalanine ammonia lyase (PAL) than rest of the cultivars in infected shoots. However, it had only significant higher PAL expression in infected roots of Harsha cultivar of ridge gourd. All the cultivars showed non-significant changes in infected shoots for tyrosine ammonia lyase (TAL) contents. In infected roots, culture BSS 1009 showed significant increase in TAL than cultivars Harsha and Aarti, however Priya only had significant higher expression of TAL than culture Harsha. For peroxidase contains, all the cultivars displayed significant variation at infected shoots and roots level. Highest increase in peroxidase was noticed in resistant than susceptible cultivars in infected shoots of different ridge gourd cultivars. In general, with few exceptions resistant cultivars had higher catalase activity both in infected shoots and roots of different ridge gourd cultivars.
\end{abstract}

\section{Introduction}

In India, the annual estimated crop losses due to major plant parasitic nematodes are estimated to the tune of Rs. 242.1 billion (Manjunatha et al. 2017). Among these plant parasitic nematodes, root-knot nematode is a major one contributing maximum losses. Ridge gourd (Luffa acutangula L.) is an important cucurbitaceous vegetable and a susceptible host crop facing considerable yield loss due to root-knot nematodes. Root-knot nematodes like many other obligate parasites can disturb the host metabolism. The changes in the physiological and biochemical processes of infected host, because of disturbed metabolism, decide whether the host becomes susceptible or resistant to nematode attack (Krusberg 1963). In this context an intimate knowledge of nematode physiology and biochemistry along with its host is absolutely essential for developing plant resistance against the nematodes. In the recent past some progress has also been made in this direction to understand the basic biochemical mechanism of plant and root-knot nematode interactions by several workers like Afifi et al. (2014) in cowpea, eggplant, papaya, Choudhary et al. (2013) in tomato, Korayem et al. (2012) in sugarbeet, Nayak (2015) in brinjal, Patel et al. (2018) in tomato and Shobha et al. (2017) in ridge gourd.

Although root-knot nematode is a major pest of ridge gourd causing major yield loss, the progress of research is very limited with respect to alteration at biochemical and physiological level. So in the present investigation several resistant and susceptible ridge gourd cultivars (both healthy and infected) against root knot nematode were investigated with an objective to identify any changes with reference to catalase, peroxidase, phenylalanine ammonia lyase (PAL) and tyrosine ammonia lyase (TAL). Detailed characterization of these parameters is essential to advance the understanding of ridge gourd - root knot nematode interaction.

*Author for correspondence: <ritupandey258@gmail.com>. 


\section{Materials and Methods}

Several susceptible and resistant ridge gourd cultivars to root knot nematode were identified on the basis of artificial screening and the present investigation was undertaken five ridge gourd cultivars i.e., Priya and BSS -1009 (resistant), Aneeta (moderately resistant), Aarti and Harsha (highly susceptible) against root knot nematode $M$. incognata. The main aim of this investigation is to find out the changes if any, with respect to catalase, peroxidase, phenylalanine ammonia lyase (PAL) and tyrosine ammonia lyase (TAL) contents in relation to ridge gourd resistant and susceptible cultivars inoculated with root knot nematode, Meloidogyne incognita. Cultivars of ridge gourd were sown in $15 \mathrm{~cm}$ diameter earthen pots filled with steam sterilized soil separately. A week after germination, one seedling per pot was retained and inoculated with axenised suspension of approximately $1000 \mathrm{~J}_{2}$ of $M$. incognita per seedling per pot. A set of uninoculated plants was used as a control. Healthy and inoculated plants were harvested at 45 days after planting. Then the shoots were surface sterilized in $1 \% \mathrm{HgCl}_{2}$ solution followed by repeated washing with distilled water. The harvested shoots were dried on blotting paper and kept separately for biochemical analysis. The following chemical compositions were estimated by different methods.

Borate buffer of $0.5,0.2 \mathrm{ml}$ enzyme solution and $1.3 \mathrm{ml}$ water were pipetted out in a test tube. The reaction was initiated by the addition of $1 \mathrm{ml} \mathrm{L}$-phenylalanine solution. It was then incubated for $30-60 \mathrm{~min}$ at $32^{\circ} \mathrm{C}$. The reaction was stopped by the addition of $1 \mathrm{M}$ trichloroacetic acid. Then a control was run in which phenylalanine was added after trichloroacetic acid. The absorbance was measured at $290 \mathrm{~nm}$ and a standard graph was prepared for trans cinnamic acid.

Leaf samples $(200 \mathrm{mg}$ ) were homogenized in $2 \mathrm{ml}$ of $25 \mathrm{~mm}$ borate buffer, $\mathrm{pH} 8.8$ containing $2 \mu \mathrm{l} \beta$-mercaptoethanol and a pinch of polyvinyl polypyrrolidone (PVP). The homogenate was filtered through the cheese cloth, centrifuged at $12,000 \times \mathrm{g}$ for $10 \mathrm{~min}$ and the supernatant was used for enzyme activity. One unit of the enzyme was defined as increase in absorbance of one unit per min. The activity of the enzyme was expressed as units per mg of soluble protein. All the steps described under PAL can be used to measure the TAL, except that the phenylalanine replaced by tyrosine. The p-coumeric acid is extracted from reaction mixture with ether and its concentration measured at $333 \mathrm{~nm}$ or alternatively at $650 \mathrm{~nm}$ using FCR.

Peroxidase enzyme activity was determined by following decrease in A420 for $1.5 \mathrm{ml}$ of a reaction mixture containing $0.45 \mathrm{ml}$ of $0.1 \mathrm{M}$ phosphate buffer $(\mathrm{pH} 7.0), 0.75 \mathrm{ml}$ of guaiacol $(8 \mathrm{mM}), 0.25 \mathrm{ml}$ solution $\mathrm{H}_{2} \mathrm{O}_{2}(18 \mathrm{mM})$ and $50 \mu \mathrm{l}$ crude enzyme extract. Enzyme activity was calculated using extinction coefficient of $25 \mathrm{mM} / \mathrm{cm}$.

The assay mixture contained $0.5 \mathrm{ml}$ of hydrogen peroxide, $1 \mathrm{ml}$ of buffer and $0.4 \mathrm{ml}$ of water. $0.2 \mathrm{ml}$ of the enzyme was added to initiate the reaction. Dichromate/acetic acid regent of $2 \mathrm{ml}$ was added after 0,30,60 and $90 \mathrm{sec}$ of incubation. To the control tube the enzyme was added after the addition of the acid reagent. The tubes were then heated for $10 \mathrm{~min}$. and then colour developed was read at $610 \mathrm{~nm}$. The activity of catalase was expressed as micromoles of $\mathrm{H}_{2} \mathrm{O}_{2}$ decomposed/ $\mathrm{min} / \mathrm{mg}$ protein.

Data were represented by means \pm SE of five individual treatments with three replications per treatment. Variance analysis was done by ANOVA following completely randomized design (CRD) design at $\mathrm{p} \leq 0.05$.

\section{Results and Discussion}

Phenylalanine ammonia lyase (PAL) contents in the resistant and susceptible ridge gourd cultivars as influenced by root knot nematode, Meloidogyne incognita are presented in Table 1 . The $\mathrm{t}$-cinnamic acid measured as $\mu$ moles per mg protein per minute of fresh shoots extract. The values 
were $0.98,0.83,0.82,0.81$ and $0.83 \mu$ moles t-cinnamic acid/mg protein/min in Priya, BSS-1009, Aneeta, Aarti and Harsha, respectively in the healthy cultivars. In the inoculated shoots these values increased many-folds to $2.77,1.03,1.04,1.01$ and $0.95 \mu$ moles $\mathrm{t}$-cinnamic acid $/ \mathrm{mg}$ protein/min, respectively registering $182.65,24.09,26.82,24.69$ and 14.45 per cent enhancement over control.

Table 1. Estimation of phenylalanine ammonia lyase contents in the resistant/susceptible ridge gourd cultivars as influenced by root knot nematode, $M$. incognita.

\begin{tabular}{|c|c|c|c|c|c|c|c|c|c|}
\hline \multirow{3}{*}{$\begin{array}{l}\text { Sl. } \\
\text { No. }\end{array}$} & \multirow{3}{*}{ Cultivars } & \multicolumn{8}{|c|}{ Phenylalanine ammonia lyase content in $\mu$ moles t-cinnamic acid $/ \mathrm{mg}$ protein $/ \mathrm{min}$} \\
\hline & & \multicolumn{4}{|c|}{ Shoot } & \multicolumn{4}{|c|}{ Root } \\
\hline & & $\begin{array}{l}\text { Infected } \\
\text { (I) }\end{array}$ & $\begin{array}{l}\text { Healthy } \\
\text { (H) }\end{array}$ & Mean & $\begin{array}{l}\text { Increase/ } \\
\text { decrease over } \\
\text { healthy }(\%)\end{array}$ & $\begin{array}{l}\text { Infected } \\
\text { (I) }\end{array}$ & $\begin{array}{l}\text { Healthy } \\
\text { (H) }\end{array}$ & Mean & $\begin{array}{l}\text { Increase/ } \\
\text { decrease over } \\
\text { healthy }(\%)\end{array}$ \\
\hline 01 & Priya & 2.77 & 0.98 & 1.87 & 182.65 & 2.20 & 1.93 & 2.06 & 13.98 \\
\hline 02 & BSS-1009 & 1.03 & 0.83 & 0.93 & 24.09 & 2.56 & 2.05 & 2.30 & 24.87 \\
\hline 03 & Aneeta & 1.04 & 0.82 & 0.93 & 26.82 & 2.50 & 1.71 & 2.10 & 46.19 \\
\hline 04 & Aarti & 1.01 & 0.81 & 0.91 & 24.69 & 2.07 & 1.82 & 1.94 & 13.73 \\
\hline \multirow[t]{3}{*}{05} & Harsha & 0.95 & 0.83 & 0.89 & 14.45 & 1.80 & 0.92 & 1.36 & 95.65 \\
\hline & $\mathrm{SE}(\mathrm{m}) \pm$ & 0.200 & 0.077 & & & 0.204 & 0.267 & & \\
\hline & $\mathrm{CD}(0.05)$ & 0.548 & 0.211 & & & 0.559 & 0.074 & & \\
\hline
\end{tabular}

It was measured as $\mu$ moles of $\mathrm{t}$-cinnamic acid formed per mg protein per minute of fresh roots extract. These were $1.93,2.05,1.71,1.82$ and $0.92 \mu$ moles $\mathrm{t}$-cinnamic acid $/ \mathrm{mg}$ protein $/ \mathrm{min}$ in Priya, BSS-1009, Aneeta, Aarti and Harsha, respectively in healthy cultivars. In the inoculated roots these values increased substantially to $2.20,2.56,2.50,2.07$ and $1.80 \mu$ moles t-cinnamic $\mathrm{acid} / \mathrm{mg}$ protein/min, respectively, registering $13.98,24.87,46.19,13.73$ and $95.65 \%$ enhancement over control.

Estimation of tyrosine ammonia lyase (TAL) contents in the resistant and susceptible ridge gourd cultivars influenced by root knot nematode, $M$. incognita is presented in Table 2 . The activity of TAL was calculated as $\mu$ moles of p-coumaric acid formed per $\mathrm{mg}$ protein $/ \mathrm{min}$ of fresh shoots. In the healthy shoots the activities were recorded as $0.93,0.97,0.93,0.81$ and $0.81 \mu$ moles t-cinnamic acid/mg protein/min in Priya, BSS-1009, Aneeta, Aarti and Harsha, respectively but in the nematode infected shoots the amounts increased remarkably by 5.10, 87.62, 73.11, 90.12 and $13.58 \%$, respectively over control.

The activity of TAL was calculated as $\mu$ moles of p-coumaric acid formed per mg protein $/ \mathrm{min}$ of fresh roots. In the healthy roots the activities were recorded as 1.71, 1.17, 0.95, 0.82 and 0.91 $\mu$ moles t-cinnamic acid/mg protein/min in Priya, BSS-1009, Aneeta, Aarti and Harsha cultivars respectively, but in the nematode infected roots the amounts increased several-folds by 31.57 , 103.41, 107.36, 121.95 and $78.02 \%$, respectively over control.

In this study higher activity of enzymes PAL and TAL were recorded in both shoots as well as roots of ridge gourd cultivars infected by root knot nematode. Cultivar Priya had significant higher activity PAL than rest of the cultivars in infected shoots; however it had only significant higher PAL expression than Harsha in infected roots of ridge gourd. All the cultivars showed nonsignificant changes in infected shoots for TAL contents. In infected roots, culture BSS 1009 showed significant increase in TAL than cultivars Harsha and Aarti, however Priya only had significant higher expression of TAL than culture Harsha. Umamaheswari et al. 2005 noticed 
higher activity of defense enzymes PAL in $M$. incognita treated plants compared to untreated plants. Nayak and Pandey 2016 also reported elevated level of PAL and TAL activities in studied cultivars of brinjal during post infection period. Mote et al. 1990 found higher activities of PAL and TAL in inoculated than un-inoculated roots and shoots samples cultivars and the values for resistant variety were considerably higher than the corresponding samples from the susceptible variety of tomato.

Table 2. Estimation of tyrosine ammonia lyase contents in the resistant/susceptible ridge gourd cultivars influenced by root knot nematode, $M$. incognita

\begin{tabular}{|c|c|c|c|c|c|c|c|c|c|}
\hline \multirow{3}{*}{$\begin{array}{l}\text { Sl. } \\
\text { No } \\
\end{array}$} & \multirow{3}{*}{ Cultivars } & \multicolumn{8}{|c|}{$\begin{array}{l}\text { Tyrosine ammonia ayase (TAL) content } \mu \text { moles of p-coumaric acid formed per mg } \\
\text { protein/min }\end{array}$} \\
\hline & & \multicolumn{4}{|c|}{ Shoot } & \multicolumn{4}{|c|}{ Root } \\
\hline & & $\begin{array}{l}\text { Infected } \\
\text { (I) }\end{array}$ & $\begin{array}{c}\text { Healthy } \\
\text { (H) }\end{array}$ & Mean & $\begin{array}{c}\text { Increase/ } \\
\text { decrease over } \\
\text { healthy }(\%)\end{array}$ & $\begin{array}{l}\text { Infected } \\
\text { (I) }\end{array}$ & $\begin{array}{c}\text { Healthy } \\
\text { (H) }\end{array}$ & Mean & $\begin{array}{c}\text { Increase/ } \\
\text { decrease over } \\
\text { healthy }(\%)\end{array}$ \\
\hline 01 & Priya & 1.03 & 0.93 & 0.98 & 5.10 & 2.25 & 1.71 & 1.98 & 31.57 \\
\hline 02 & BSS-1009 & 1.82 & 0.97 & 1.39 & 87.62 & 2.38 & 1.17 & 1.98 & 103.41 \\
\hline 03 & Aneeta & 1.61 & 0.93 & 1.27 & 73.11 & 1.97 & 0.95 & 1.46 & 107.36 \\
\hline 04 & Aarti & 1.54 & 0.81 & 1.17 & 90.12 & 1.82 & 0.82 & 1.32 & 121.95 \\
\hline \multirow[t]{3}{*}{05} & Harsha & 0.92 & 0.81 & 0.86 & 13.58 & 1.62 & 0.91 & 1.26 & 78.02 \\
\hline & $\mathrm{SE}(\mathrm{m}) \pm$ & 0.334 & 0.026 & & & 0.197 & 0.288 & & \\
\hline & $\mathrm{CD}(0.05)$ & 0.915 & 0.071 & & & 0.539 & 0.789 & & \\
\hline
\end{tabular}

The enhanced activity of both the enzymes and appearance of aromatic amino acids like tyrosine and phenylalanine in inoculated samples appears to be interesting and significant. These amino acids are known to have significant role in lignifications. Both t-cinammic acid and Pcoumaric acids, the product of TAL and PAL activities, respectively are lignin precursors and play significant role in defense mechanism.

Estimation of peroxidase contents in the resistant and susceptible ridge gourd cultivars influenced by root knot nematode, $M$. incognita are presented in Table 3 . The increased peroxidase activity was observed in nematode inoculated shoots samples of both susceptible and resistant ridge gourd cultivars, but higher enzymatic activity was recorded in resistant cultivars and registered 35.34, 20.58, 19.83, 8.92 and 50.47\% increase over control in the cultivars Priya, BSS1009, Aneeta, Aarti and Harsha, respectively. The increased peroxidase activity was observed in nematode inoculated roots samples of both susceptible and resistant ridge gourd cultivars, but higher enzymatic activity was recorded in resistant cultivars and registered 67.58, 86.26, 77.21, 53.01 and $54.91 \%$ increase over control in the cultivars Priya, BSS-1009, Aneeta, Aarti and Harsha, respectively.

Estimation of catalase contents in the resistant/susceptible ridge gourd cultivars influenced by root knot nematode, $M$. incognita is presented in Table 4 . The catalase activity was increased by 25.42, 32.74, 24.25, 33.90 and 53.34\% in case of nematode inoculated cultivar, Priya, BSS-1009, Aneeta, Aarti and Harsha, respectively. Whereas, its activity was increased considerably in resistant cultivars inoculated with root-knot nematode over control. The formation of giant cells and galls in plants, susceptible to the endoparasitic nematode was a function of increased level of auxin (Giebel 1973). 
The catalase activity increased by $7.76,14.39,46.51,57.44$ and $52.83 \%$ in case of nematode inoculated cultivars, Priya, BSS-1009, Aneeta, Aarti and Harsha, respectively. Whereas its activity was increased considerably in resistant cultivars inoculated with root-knot nematode over control. The catalase activity in inoculated cultivars increased by $18.87,14.54,8.19,8.14$ and 9.17 units/mg protein/min and was decreased in healthy cultivars.

Table 3. Estimation of peroxidase contents in the resistant/susceptible ridge gourd cultivars influenced by root knot nematode, $M$. incognita.

\begin{tabular}{|c|c|c|c|c|c|c|c|c|c|}
\hline \multirow{3}{*}{$\begin{array}{l}\text { Sl. } \\
\text { No. }\end{array}$} & \multirow{3}{*}{ Cultivars } & \multicolumn{8}{|c|}{ Peroxidase content in units/mg protein/min } \\
\hline & & \multicolumn{4}{|c|}{ Shoot } & \multicolumn{4}{|c|}{ Root } \\
\hline & & $\begin{array}{l}\text { Infected } \\
\text { (I) }\end{array}$ & $\begin{array}{c}\text { Healthy } \\
\text { (H) }\end{array}$ & Mean & $\begin{array}{l}\text { Increase/ } \\
\text { decrease over } \\
\text { healthy }(\%)\end{array}$ & $\begin{array}{c}\text { Infected } \\
\text { (I) }\end{array}$ & $\begin{array}{c}\text { Healthy } \\
\text { (H) }\end{array}$ & Mean & $\begin{array}{l}\text { Increase/ } \\
\text { decrease over } \\
\text { healthy }(\%)\end{array}$ \\
\hline 01 & Priya & 63.99 & 47.28 & 55.63 & 35.34 & 126.81 & 75.67 & 101.24 & 67.58 \\
\hline 02 & BSS-1009 & 76.69 & 63.60 & 70.14 & 20.58 & 117.16 & 62.9 & 96.41 & 86.26 \\
\hline 03 & Aneeta & 82.36 & 68.73 & 75.54 & 19.83 & 103.30 & 58.29 & 80.79 & 77.21 \\
\hline 04 & Aarti & 54.46 & 50.00 & 52.23 & 8.92 & 122.64 & 80.15 & 101.39 & 53.01 \\
\hline \multirow[t]{3}{*}{05} & Harsha & 60.61 & 40.28 & 50.44 & 50.47 & 115.47 & 74.54 & 95.01 & 54.91 \\
\hline & $\mathrm{SE}(\mathrm{m}) \pm$ & 0.311 & 4.938 & & & 0.350 & 0.493 & & \\
\hline & $\mathrm{CD}(0.05)$ & 0.852 & 13.535 & & & 0.959 & 1.351 & & \\
\hline
\end{tabular}

Table 4. Estimation of catalase contents in the resistant/susceptible ridge gourd cultivars influenced by root knot nematode, $M$. incognita.

\begin{tabular}{|c|c|c|c|c|c|c|c|c|c|}
\hline \multirow{3}{*}{$\begin{array}{l}\text { Sl. } \\
\text { No. }\end{array}$} & \multirow{3}{*}{ Cultivars } & \multicolumn{8}{|c|}{ Catalase content in units/mg protein/min } \\
\hline & & \multicolumn{4}{|c|}{ Shoot } & \multicolumn{4}{|c|}{ Root } \\
\hline & & $\begin{array}{l}\text { Infected } \\
\text { (I) }\end{array}$ & $\begin{array}{c}\text { Healthy } \\
\text { (H) }\end{array}$ & Mean & $\begin{array}{l}\text { Increase/ } \\
\text { decrease over } \\
\text { healthy }(\%)\end{array}$ & $\begin{array}{c}\text { Infected } \\
\text { (I) }\end{array}$ & $\begin{array}{l}\text { Healthy } \\
(\mathrm{H})\end{array}$ & Mean & $\begin{array}{l}\text { Increase/ } \\
\text { decrease over } \\
\text { healthy }(\%)\end{array}$ \\
\hline 01 & Priya & 9.62 & 7.67 & 8.64 & 25.42 & 18.87 & 17.51 & 18.19 & 7.76 \\
\hline 02 & BSS-1009 & 9.73 & 7.33 & 8.53 & 32.74 & 14.54 & 12.71 & 13.62 & 14.39 \\
\hline 03 & Aneeta & 13.01 & 10.47 & 11.74 & 24.25 & 8.19 & 5.59 & 6.89 & 46.51 \\
\hline 04 & Aarti & 7.03 & 5.25 & 6.14 & 33.90 & 8.14 & 5.17 & 6.65 & 57.44 \\
\hline \multirow[t]{3}{*}{05} & Harsha & 6.18 & 4.03 & 5.10 & 53.34 & 9.17 & 6.00 & 7.58 & 52.83 \\
\hline & $\mathrm{SE}(\mathrm{m}) \pm$ & 0.176 & 0.298 & & & 0.204 & 0.221 & & \\
\hline & $\mathrm{CD}(0.05)$ & 0.482 & 0.816 & & & 0.559 & 0.605 & & \\
\hline
\end{tabular}

The results indicated an elevated level of peroxidase and catalase activities during postinfection period. For peroxidase contains, all the cultivars displayed significant variation at infected shoots and roots level. Highest increase in peroxidase was noticed in resistant than susceptible cultivars in infected shoots of different ridge gourd cultivars. In general, with few exceptions resistant cultivars had higher catalase activity both in infected shoots and roots of different ridge gourd cultivars. The increase in level of peroxidase activities was reported by 
Mohanty et al. (1988), Kalirasan et al. (2006), Chawla and Pankaj (2007), Nayak and Pandey (2016) in different crops. This increase in peroxidase activity was possible due to synthesis of new iso enzymes as a response to nematode infection. Rani et al. (2008) and Sundharaiya et al. (2011) found higher peroxides level in resistant cultivars as compared to susceptible cultivars of tamato in different investigation. Peroxidase is often cited as one of the key enzymes require for lignin biosynthesis and phenol metabolism. Further superoxide radicals and singlet $\mathrm{O}_{2}$ can be generated from NADH and $\mathrm{H}_{2} \mathrm{O}_{2}$ through the action of catalase and peroxidase, respectively, which are linked with resistant reactions of the host plant.

Here higher activity of enzymes PAL and TAL was recorded in shoots as well as roots of ridge gourd cultivars infected with root knot nematode. Both t-cinammic acid and P-coumaric acids the product of TAL and PAL activities, respectively is lignin precursors and play significant role in defense mechanism. Elevated level of peroxidase and catalase activities during post-infection period was recorded in shoots as well as roots of ridge gourd cultivars. This increase in peroxidase activity might be due to synthesis of new isoenzymes as a response to nematode infection. Peroxidase is often cited as one of the key enzymes require for lignin biosynthesis and phenol metabolism. Further superoxide radicals and singlet $\mathrm{O}_{2}$ can be generated from NADH and $\mathrm{H}_{2} \mathrm{O}_{2}$ through the action of catalase and peroxidase, respectively which are linked with resistant reactions of the host plant.

It can be inferred from the present study that the root knot nematode Meloidogyne incognita induce major biochemical changes in plants. Understanding the biochemical and molecular basis of plant nematode interaction will help us in identifying new targets to intervene with nematode parasitism and develop novel strategies to combat them. The information generated from this investigation can be manipulated through advanced biotechnological research for planning suitable management strategies. The present study provides same basic information relating to hostpathogen interaction and biochemical mechanism of resistance. The above knowledge of physiological and bio-chemical events during the post-infection period have initiated search for molecules, which can trigger the function of enzymes involve in hyper sensitive response, production of phytoallexins lignin or other secondary metabolites which are detrimental to nematode feeding and development.

Finally, the present investigation clearly indicated that Meloidogyne incognita played key role in altering the normal physiology and biochemical processes of the tested host plant. Detailed characterization of these parameters is essential to advance the understanding of ridge gourd - root knot nematode interaction and complicated areas of the biochemical mechanisms. This information would be of greatly helpful to plant breeders and nematologists for development of new resistant ridge gourd against root knot nematode, also formulating new management strategy.

\section{References}

Afifi AMR, Al-Sayed AA, Mahfoud NAM and Farahat AA 2014. Enzymatic and non-enzymatic oxidants and antioxidants involved in defense mechanisms against root-knot, reniform and citrus nematodes in their hosts. Egypt. J. Agronematol. 13(1): 172-188.

Chawla G and Pankaj 2007. Biochemical basis of resistance in chickpea varieties against the root- knot nematode, Meloidogyne incognita. Indian J. Nematol. 37(1): 105.

Choudhary K, Chawla N, Kaur S and Jindal S 2013. Analysis of biochemical parameters in tomato fruits before and after inoculation with root knot nematode (Meloydogyne incognita). Vegetable Science 40(2):178-181.

Giebel J 1973. Enzyme phenylalanine ammonia lyase (PAL) and tyrosine ammonia lyase (TAL) activities in potato roots and their significance in potato resistant to Heterodera rostochiensis. Nematologica 19(1): $1-6$. 
Kalirasan P, Lakshmanan PL and Samiyappan R 2006. Influenced of P. fluorescens on histopathological changes caused by M. arenarea in G/n (Arachis hypogeal L.). Indian J. Nematol. 36(2): 305-307.

Korayem A, El-Bassiouny H, El-Monem, Amany and Mohamed M 2012. Physiological and biochemical changes in different sugarbeet genotypes infected with root-knot nematode. Acta Physiologiae Plantarum. 34. 10.1007/s11738-012-0983-1.

Krusberg LR 1963. Host response to nematode infection. Annu. Rev. Phytopathol. 1: 219-240.

Manjunatha T, Gowda AB, Rai and Singh B 2017. Root knot nematode: A treat to vegetable production and its management. IIVR Technical Bulletin No. 76, IIVR, Varanasi. 32 pp.

Mohanty KC, Ganguly SK and Dasgupta DR 1988. Partial purification and concentration of peroxidase from two varieties of cowpea inoculated with root-knot nematode $M$. incognita. Indian J. Nematol. 18(2); $252-262$.

Mote UN, Dasgupta DR and Ganguly AK 1990. Sequential development of deaminases in resistant and susceptible tomato varieties infested with root-knot nematode, Meloidogyne incognita. Indian J. Nematol. 20(2): 127-137.

Nayak DK 2015. Effects of nematode infection on contents of phenolic substances as influenced by rootknot nematode, Meloidogyne incognita in susceptible and resistant brinjal cultivars. Agr. Sci. Digest. 35: $163-164$.

Nayak DK and Pandey RK 2016. physiological and biochemical changes of susceptible and resistant brinjal cultivars induced by root-knot nematode, Meloidogyne incognita. Journal of Global Biosciences 5(7): 4358-4368.

Patel VS, Pitambara and Shukla YM 2018. Biochemical characterization of root knot nematode (Meloidogyne incognita) infected tomato cultivar (Solanum lycopersicum L.). J. Pharmacogn. and Phytochem.7(5): 1621-1629

Rani DI, Ragavathatham V and Sanjutha S 2008. Analysis on biochemical basis of root-knot nematode (Meloidogyne incognita) resistance in tomato (Lycopersicon esculentum Mill.). Res. J. Agri. Bio. Sci. 4(6): 866-870.

Shobha G, Kantharaju V and Amaresh YS 2017. Changes in biochemical parameters in healthy and root-knot nematode infested varieties of ridge gourd. Indian J. Nematol. 6(1): 15-18.

Sundharaiya K, Jansirani, P and Sivakumar M 2011. Biochemical response of tomato genotypes to Meloidogyne incognita. Ann. Pl. Prot. Sci. 19(1): 193-198.

Umamaheswari R, Sivakumar M, Subramanian S and Samiyappan R 2005. Biochemical and physiological alternations induced in green gram by $T$. viridae against root-knot nematode $M$. incognita. National Symposium on Recent Advances and Research Priorities in Indian Nematology 9-10 December, IARI, New Delhi, pp. 53. 